\title{
鋼 管トラス梁の横座屈
}

（鋼管構造に関する研究）

正会員鈴 “木 敏 郎*

\section{1. 鋼管構造と座屈}

鉄骨構造の建築物を設計する際，建築の機能的な要求 々力学的に構造の条件を満すこと以外に構造的な美しさ も極めて重要な点となる。特に工場・大ホール・体育館 のような大構造物では，骨組の美しさが設計上強く要求 される。近年鋼管構造がこの種建築に好んで用いられる のは, 鋼管構造が以上の要求に適切な解決を与えてくれ たからである。

近年鋼管が構造用の主要材料として注目されるに至っ たのは，戦後における溶接工法の急速な進歩と管端加工 法など施工上の大問題が一挙に解決されたことによる。 しかる鋼管構造では仕口・接合部の構造が簡潔なとと以 外に鋼管材料の構造力学上の有利さから鋼材量の低減が 可能となり（実例による検討では圧延形鋼による建築物 飞比し鋼材量は 60 80\% の低減も可能であるといわれ ている)，鋼管材料自身の費用高もうめあわされるほど である。

鋼管材料の力学的有利さは主として王縮材の座屈に対 し発揮される。鋼管は単一材でも組立材についても他の 鋼材にくらべ座屈に対し極少て安全性の高いものと考え られる。鋼管の有利さは主にその断面形による, 即ち鋼 管のような閉鎖形断面の部材は他の開放形断面の部材に くらべ次のような利点が考えられるからである。まづ据 り座屈や局部來屈に対方危険性が少なく座屈後の大変 形に対しても耐力低下が緩慢であること。又塑性領域の 予備耐力が大きいことである。別に断面の回転半径・核 は広く且つ方向性もなく元暁み偏心に対して有利であ り，しかも設計上生ずる偏心は比較的小さいことによ る。

特に鋼管組立材は横座屈に対し特異な性質を示す。即 ち鋼管材料の断面性能特に揬り剛性が高いととおよび製 作上剛節構造が可能であるととにより，曲げと据りの連 成する横座屈に対して極めて大きな耐力を期待出来る。 大スパンの梁ではてれが著るしく，大スパン鉄骨構造に お污る鋼管材料の有用性も高い。

\section{2. 横座屈理論式}

本研究は平行弦剛節トラス梁の横座屈問題を扱ったも のである。こつでいう平行弦トラスとは両弦材が 1 本材

* 名古屋工業大学講師 工博

(昭和 39 年 1 月 20 日本稿受理, 討論期限 39 年 8 月末日)

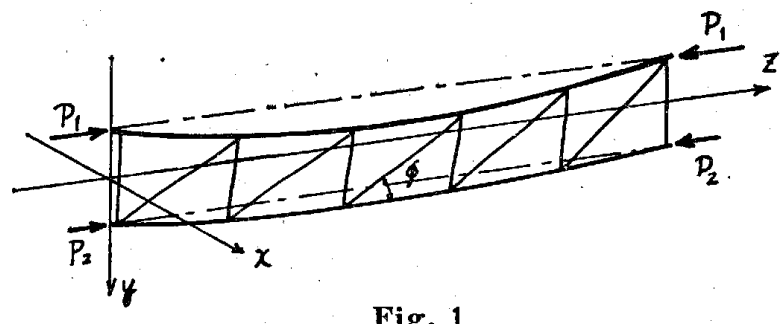

Fig. 1

として平行に通りウェブ材はそれと剛節したトラスであ る。なおこの研究の対象はトラス梁全体の安定問題であ って, 従ってトラスを構成のる各個材ないしはトラス接 合点の部分的な構面外座屈は考えていない。

解析はエネルギー法により，Fig. 1 亿示すように平行 茲トラスが上下弦材に一定の軸方向力をうけて横座屈す る場合である。なお材端は単純支持とし, 又横荷重のあ る梁は考光ないことにする。エネルギー式誘導にあたっ ては，腹材は弦材と剛に接して座屈変形すると仮定して いる。

以下誘導された結果のみ示す1)。なお一般に平行弦卜 ラスは上下非対称とし各弦材を suffix 1，2で区別し，ウ エブ材については斜材预よび垂直材をそれぞれ $d, v$ と する。結局最終的に求められた単純支持平行弦卜ラスの 一般解は次の通りである。

$$
\left|\begin{array}{cc}
u_{1} & u_{2} \\
-P_{1}+\frac{\pi^{2}}{l^{2}} B_{1}+\frac{1}{h^{2}} C & -\frac{1}{h^{2}} C \\
-\frac{1}{h^{2}} C & -P_{2}+\frac{\pi^{2}}{l^{2}} B_{2}+\frac{1}{h^{2}} C
\end{array}\right|=0
$$

Eq. 1

と〉で

$$
\begin{aligned}
& C=\delta_{1} C_{1}+\delta_{2} \mathrm{C}_{2}+\left(B_{w}+C_{w}\right) \\
& \mathrm{B}_{w}=\cot \phi \cdot \sin ^{3} \phi \cdot B_{d} \\
& \mathrm{C}_{w}=\tan \phi\left(\sin ^{3} \phi C_{d}+C_{v}\right)
\end{aligned}
$$

Eq. 2

なお， $B$ : 曲げ剛性, $C$ : 据り剛性, $P$ : 弦材の軸力 (符 号は圧縮のとき正)， $l:$ はリスパン， $h:$ はりせいであ る。

式中 $B_{w} ， C_{w}$ はトラス構面の 据り変形に対する腹材の曲げおよ び据り抵抗で, $\left(B_{w}+C_{w}\right)$ はトラ ス腹材の等価㨝り剛性と考元るこ とが出来る。たぶ一般には弦材の 㧖り剛性にくらべ小さな值である

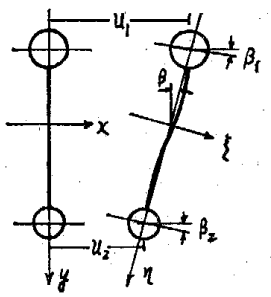

Fig. 2 
ため省略して差しつかえない。又 $\delta_{1}, \delta_{2}$ はトラス構面の 据り角 $\beta$ 之弦材の据り角 $\beta_{1} ， \beta_{2}$ との比を表わし，一般 に $0<\delta<1$ の值である。乙れは Fig. 2 の如く腹材が卜 ラス構面外に曲げ変形するため生ずるもので, 結果から みれば弦材据り剛性の見掛け上の低下率と考えることが 出来る。 $\delta$ は弦材の㨭り剛性之腹材の曲げ剛性に関係し た值で，簡単に次の值としてよい。

$$
\left.\begin{array}{l}
\delta_{1}=\frac{1}{1+C_{1} / 6 B^{\prime}} \\
\delta_{2}=\frac{1}{1+C_{2} / 6 B^{\prime}}
\end{array}\right\}
$$

Eq. 3

こ〉で $B^{\prime}$ はトラス構面外への腹材の等価曲げ剛性 ${ }^{2)}$ に 相当する。

$$
B^{\prime}=\left(\frac{l}{\pi h}\right)^{2} \tan \phi\left(\sin ^{3} \phi \cdot B_{d}+B_{v}\right)
$$

結局この結果は一般に I 形断面材について得られる式 である。即ちトラス全体の曲げ・垁り・曲げ㧖り各剛性 を I 形鋼と同様に $B \cdot C \cdot C_{b d}$ として次の関係と

$$
\begin{aligned}
& B=B_{1}+B_{2} \\
& C=\delta_{1} C_{1}+\delta_{2} C_{2}+\left(B_{w}+C_{w}\right) \\
& C_{b d}=\frac{h^{2} B_{1} B_{2}}{B_{1}+B_{2}}
\end{aligned}
$$

外力については中心圧縓力 $P$ と曲げモーメント $M$ で表 現すると，I 形断面材の横座屈に対し得る通常の式に変 換出来る。即ち平行弦トラスはI 形単一材の横座屈問題 として扱いうるととである。

以上要するに

i ） トラスの断面常数は各弦材をフランジとするI 形断面材と考えてよい。

ii） トラス腹材の曲げおよび据 り剛性は無視する。

iii）ウェプ材の曲げ変形を生ず るおそれがある場合は弦材の据り剛 性に対して見掛け上の低下を考え る。

以上は外力一定両端単純支持の平 行弦トラスに対する結果であるが， I 形単一材との関係を知ったので, 他の境界条件・荷重状態については 単一材に関して得られている結果を そのま〉利用出来る。最後にトラス の横座屈について注意すべき点を列 記し考察する。

弦材之腹材の接合条件 との解 析では弦材と腹材の接合条件は剛節 亡仮定したが，形鏩トラスのように この条件を满さない場合がある。剛 節条件が不完全になると腹材の曲げ 変形のときと同様フランジの㧖り剛
性を見掛上低下して考える必要があ る。Fig. 3 のように完全にピン接 合の場合は $\delta=0$ である。

腹材構成の粗さ理論式誘導の 途中で腹材構成区間 $s$ はスパン $l$ に 比べ小いものと仮定しているが๋ 経験的に腹材の区分数は $3 \sim 4$ 以上

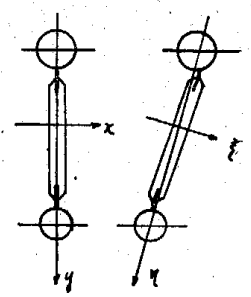

Fig. 3 では問題ないと考えられる。、トラス構面の大きな構成の 粗いものでは各材の位置関係が重要となり解析も容易で ない。

腹材に作用する応力 横荷重をうける梁の問題は I 形単一材に対し得られている結果を利用して解決出来 る。たぶトラスになるとせん断力により腹材に軸力が生 ずるので注意を要する。

\section{3. 水平加力による横座屈実験}

既に柱の実験によって鋼管・形鋼と断面性能の異なっ た 2 種類の組立材にういて横座屈性状の概略は知っ だ。その結果鋼管組立材の有利なととにふれたが，特

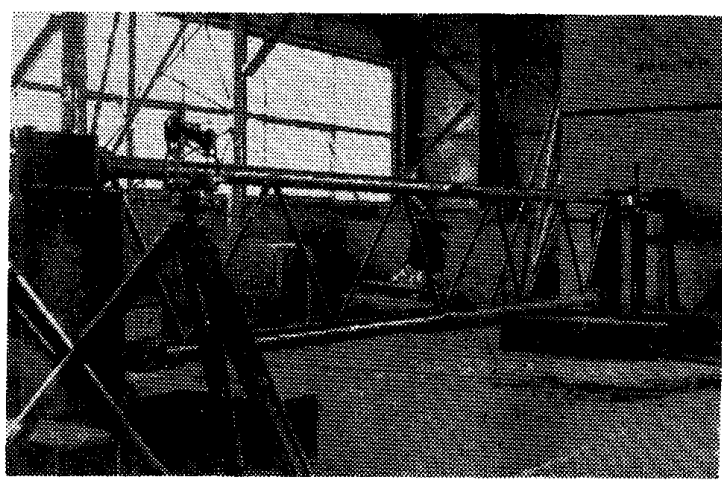

Photo. 1

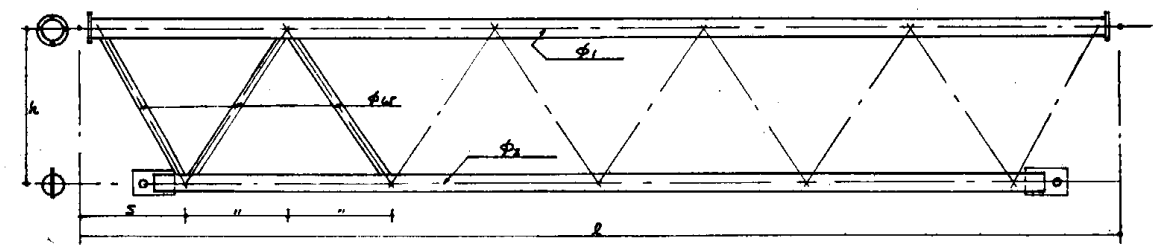

Fig. 4
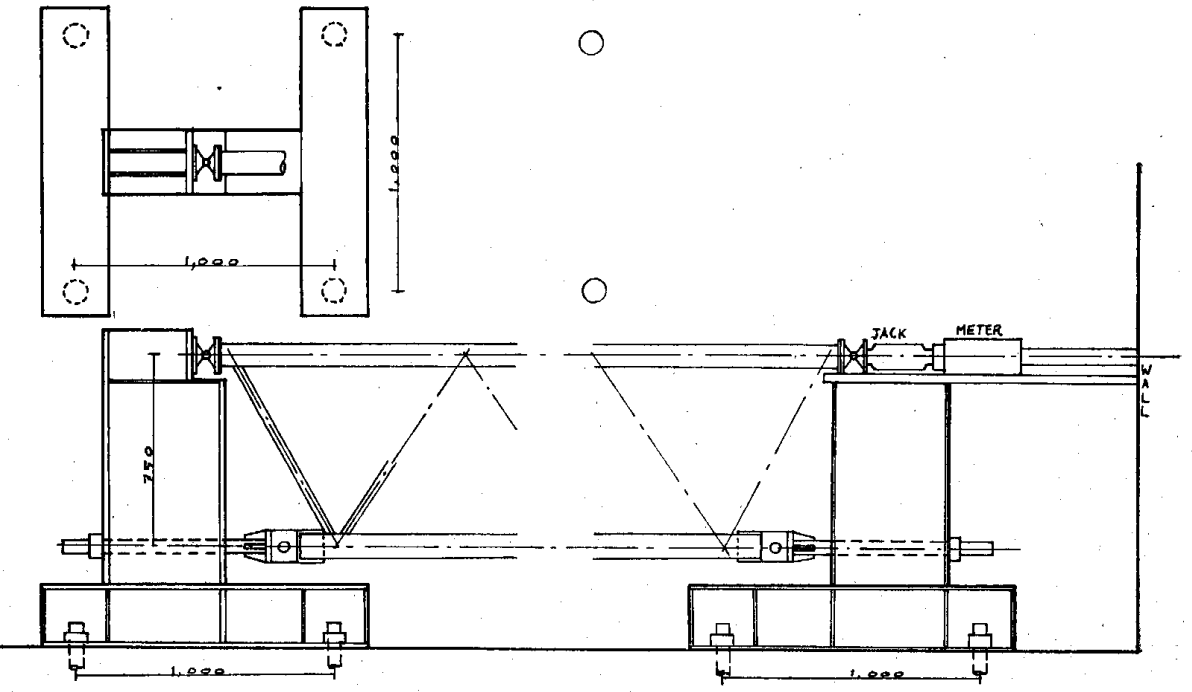

Fig. 5 
Table 1

\begin{tabular}{|c|c|c|c|c|c|c|c|}
\hline \multicolumn{2}{|c|}{ Tested-beams } & \multicolumn{3}{|c|}{ Dimension ( $\mathrm{mm}$ ) } & \multicolumn{3}{|c|}{ Steelpipe } \\
\hline Type & $P_{2}$ ton & $l$ & $h$ & $\hat{s}$ & $\phi_{1}$ & $\phi_{2}$ & $\phi_{w}$ \\
\hline$W-3$ & 0,10 & 3,000 & 750 & 500 & $89.1 \times 4.0$ & $76.3 \times 3.2$ & $34.0 \times 2.2$ \\
\hline W-4 & 0,10 & 4,000 & " & " & " & " & " \\
\hline$W-5$ & $0,5,10,15$ & 5,000 & " & " & " & " & $"$ \\
\hline W-6 & 0,10 & 6,000 & " & $"$ & $"$ & $\Rightarrow$ & " \\
\hline W-7 & 0,10 & 7,000 & $"$ & is & " & $"$ & $"$ \\
\hline$W^{\prime}-5$ & 0,10 & 5,000 & $"$ & " & $"$ & $89.1 \times 4.0$ & $"$ \\
\hline$W^{\prime \prime}-5$ & 0,10 & 5,000 & $\Rightarrow$ & " & $"$ & $101.4 \times 5.0$ & $"$ \\
\hline
\end{tabular}

し横ぶれを防ぐため支持台のボルトにとめた。 上弦材の圧縮力はループメータにより, 下弦材 の引張力は支持台のボルトに貼った W.S.G より計測した。この実験では最初一定の引張力 をかけその後トラス上弦材に加力した〉め, 単 純な曲げ応力状態ではない。勿論ての結果から 他の荷重条件での座屈而力㹥類推出来る。又卜 ラス圧縮弦材の両端は球座をとりつけピン支点 としたが，下弦材の拘束はやむをえない。

まづ使用した鋼管素材の引張陚験結果を Table 2.に 示す。Table 3 は各試験 体の座屈荷重で，実験值は 破壊したときの最高荷重, 理論值はウェブの剛性を省 略した略算值である。実験 值は 1 2 本をのぞいて 1 割前後の誤差であるが，て のばらつきの主な原因は武 験体をとめたボルトの拘束 が一定しないことによる。 ぐ予備的に行なった単一材 たの結果から，上弦材の加 力方法打よび材端球座と問

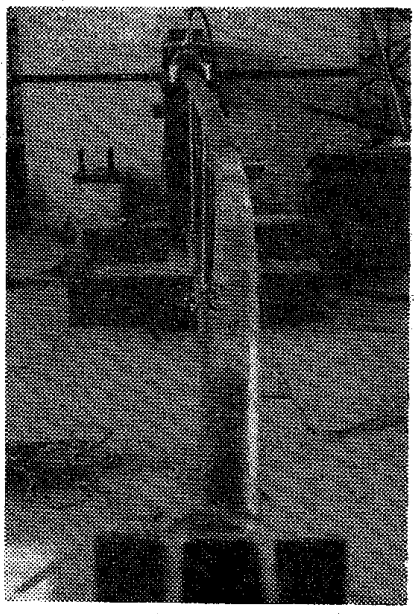

Photo. 2 に示す。

Fig. 5 は実験装置の詳細である。試験体は 2 台の支 持台の間に支え，一方の端部方ら加力する。トラス上弦 材の圧縮力はオイルジャッキ(手動 30 tons)により,下弦 材の引張力は両端支持台にとめられたボルトによる。な お下弦材に引張力をかけない場合も，端部条件を一定に

Table 2

\begin{tabular}{lcccc}
\hline Test-piece & Material & $\begin{array}{c}\text { Yield-point } \\
\left(\mathrm{kg} / \mathrm{mm}^{2}\right)\end{array}$ & $\begin{array}{c}\text { Tensile- } \\
\text { strength } \\
\left(\mathrm{kg} / \mathrm{mm}^{2}\right)\end{array}$ & $\begin{array}{c}\text { Elongation } \\
(\%)\end{array}$ \\
\hline$\phi-101.6 \times 5.0$ & S T K 41 & 33.5 & 50.5 & 34.2 \\
$\phi-89.1 \times 4.0$ & S T K 41 & 34.0 & 42.4 & 43.9 \\
$\phi-76.3 \times 3.2$ & S T K 41 & 33.9 & 41.8 & 45.5 \\
$\phi-34.0 \times 2.2$ & S T K 41 & 38.5 & 43.3 & 44.5 \\
\hline
\end{tabular}

Table 3

\begin{tabular}{cccc}
\hline Tested beams & $\begin{array}{c}\text { Experimental } \\
\text { results(ton) }\end{array}$ & $\begin{array}{c}\text { Theoretical } \\
\text { loads(ton) }\end{array}$ & $\begin{array}{c}\text { Ratio } \\
(\%)\end{array}$ \\
\hline W-3.0 & 24.0 & 28.1 & -14.6 \\
W-3.10 & 27.7 & 30.0 & -7.7 \\
W-4.0 & 19.0 & 17.2 & +10.4 \\
W-4.10 & 18.5 & 21.0 & -11.9 \\
W-5.0 & 10.5 & 11.4 & -7.9 \\
W-5.5 & 16.6 & 14.4 & +15.3 \\
W-5.10 & 18.0 & 16.5 & +9.1 \\
W-5.15 & 18.1 & 18.1 & 0.0 \\
W-6.0 & 11.4 & 8.1 & +40.7 \\
W-6.10 & 17.4 & 14.1 & +23.4 \\
W-7.0 & 6.4 & 6.1 & +5.0 \\
W-7.10 & 13.8 & 12.5 & +10.4 \\
$W^{\prime}-5.0$ & 14.8 & 14.1 & +5.0 \\
W'-5.10 & 18.8 & 18.5 & +1.6 \\
W'-5.0 $^{\prime \prime}-5.5$ & 17.8 & +6.7 \\
W'-5.10 $^{\prime \prime}$ & 19.0 & 21.3 & -6.1 \\
\hline
\end{tabular}

題になる点はなかった。

Fig. 6 (a)，(b)，(c) は座屈荷重の理諭曲線之実験值 を示したものである。（a）は材長を変えた場合の座屈荷 重を図示したもので，標準形非対称トラスの例である。 太い実線は下弦材の軸力が 0 のときと引張力 10 ton が 加わったときの理論曲線で, 細い実線は一定曲げモーメ ントが加わった場合之圧縮弦材単材のオイラ一座屈の理 論曲線である。(b) 梅準形トラス W-5 について下弦 材の軸力を変化させたときの座屈荷重を示す。（c）は同 ビく材長 $l=5 \mathrm{~m}$ の トラスで下弦材の鋼 管材料を変光即ち下 弦材の㓮性之座屈荷 重の関係を図示した もので, 下弦材の軸 力 $P_{2}=0,-10$ ton の例である。なお各 図とも座屈荷重は卜 ラス上弦材の圧縮力 $P_{1}$ で表現したもの である。又実験值は 図中にプロットした が, 注意すべき点は 下弦材の軸力は初期 応力として入ってい

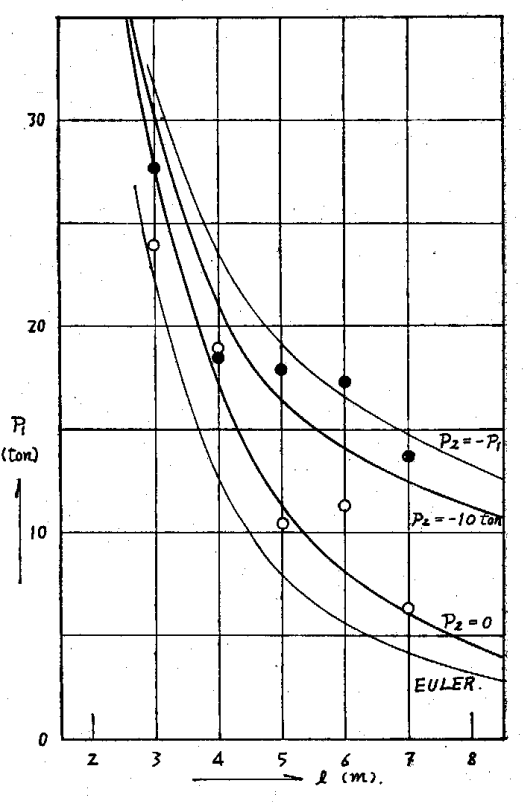

(a)

Fig. 6 


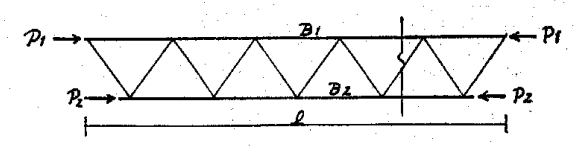

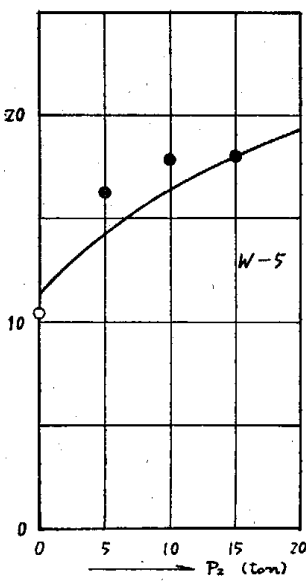

(b)

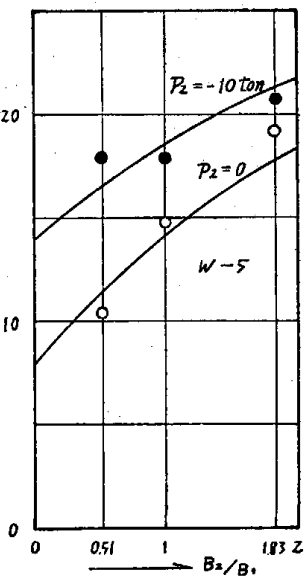

(c)
Fig. 6

るため梁全体の軸力 $P$ と曲げ $M$ の比率注座屈荷重 $P_{1}$ 往って変ることである。

以上の各結果を綜合して, 剛節トラスの横座屈に対す る特性を列記すれぱ次の通りである。

i）下弦材に引張力がある場合即ち梁では大スパン になっても耐力の低下は緩慢である。言いかえれば压縮 弦材単材のオイラ一座屈值よりはるかに高い耐力を示 す。

ii）下弦材の軸力の影響は 0 の近傍で著るしく変化 する。

iii）下弦材の剛性の影響はその応力とも関係し, 軸 力が 0 のときはほら゙その凪性の比に従い引張力が加われ ば差は小さくなる。

\section{4. 補足実験-腹材の曲げ変形}

鋼管のように挨り剛性の高い鋼材で組立てられたトラ スは，先に述べた通り横座屈に対し有利であるが，同時

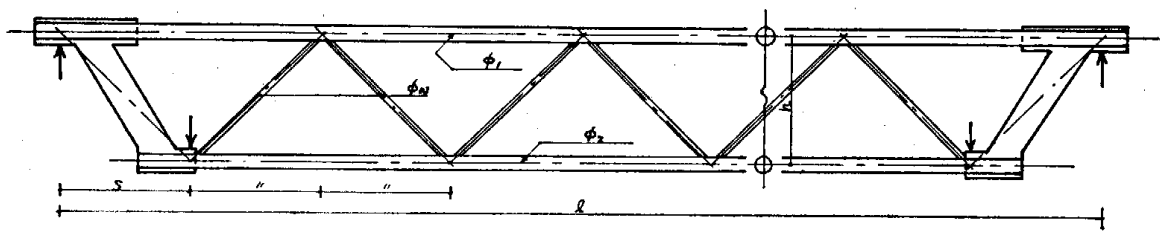

Fig. 7

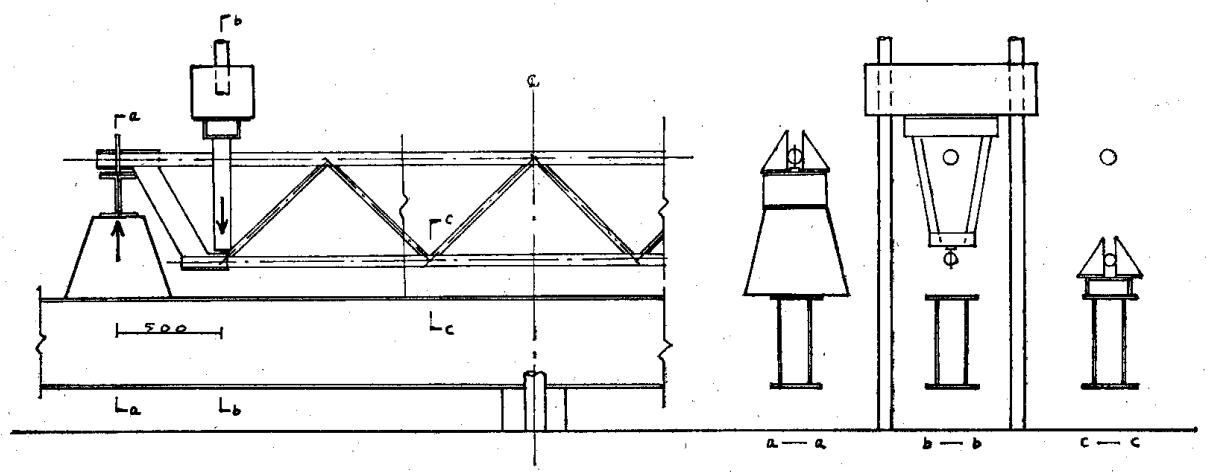

Fig. 8
Table 4

\begin{tabular}{|c|c|c|c|c|}
\hline \multicolumn{2}{|c|}{ Type of Beans } & \multicolumn{3}{|c|}{ Dimension (mm) } \\
\hline & & la & $h$ & $s$ \\
\hline$A-1$ & B-1 & 4,000 & 500 & 500 \\
\hline$A-1$ & B-2 & 6,000 & 500 & 500 \\
\hline
\end{tabular}

Table 5

\begin{tabular}{ccccc}
\hline Test-piece & Material & $\begin{array}{c}\text { Yield-point } \\
\left(\mathrm{kg} / \mathrm{mm}^{2}\right)\end{array}$ & $\begin{array}{c}\text { Tensile- } \\
\text { strengh } \\
\left(\mathbf{k g} / \mathbf{m m}^{2}\right)\end{array}$ & $\begin{array}{c}\text { Elongation } \\
(\%)\end{array}$ \\
\hline$\phi_{1}-60.5 \times 2.8$ & S T K 41 & 38.8 & 47.4 & 30.5 \\
$\phi_{2}-48.6 \times 2.3$ & S T K 41 & 36.4 & 46.1 & 31.5 \\
$\phi_{w}-21.7 \times 1.9$ & S KT 41 & 47.0 & 60.3 & 27.5 \\
\hline
\end{tabular}

に腹材の曲げ変形が座屈酎力に大きく影響する。即ちつ ランジ㨝り剛性の見掛上の低下率 $\delta に$ 対する検討も重 要となる。梁は単純支持・外力は一定曲げモーメントの 横座屈実験で，下弦材の横移動を拘束した場合について も実験した。

試験体は Fig. 7 の非対称ワーレン形トラスで，種類 並びに記号は Table 4 亿示す。材料武験結果は Tabl 5 の通りである。梁に曲げをかける場合材端条件を明確に して載荷するととがむつかしいが，乙の実験では Fig. 8 の装置で行なった。両材端から $50 \mathrm{~cm}$ の位置に荷重を かけ梁に一定の曲げモーメントを与えた。即ち上・下弦

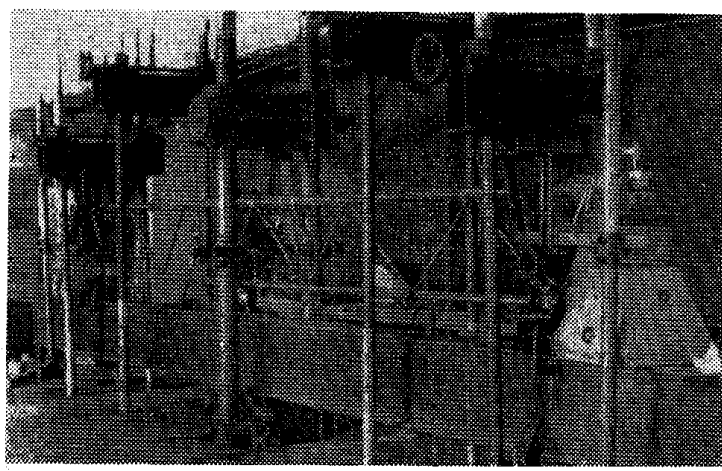

Photo. 3

材には一定の軸力が生じ，腹材には せん断力はない。なお下弦材に載荷 し上弦材の拘束は少なくしたが，端 部の多少の拘束はやむをえない。又 下弦材の横移動をとめた場合は支え をトラス各節点に断綕的に配 置し た。試験機は 200 tons 压縮・曲げ武 験機（東京工大）である。

各試験体の座屈荷 重は Table 6 に示す。この実験值は試験機からの 直接の結果ではなく，材中央に貼っ たW・S・G により測定した弦材の 応力から修正を加えた值である。乙 れは材端部の短い区間で載荷してい るため直接の荷重では不正確だと考 


\section{Table 6}

\begin{tabular}{cccc}
\hline Tested beams & $\begin{array}{c}\text { Experimental } \\
\text { results (ton) }\end{array}$ & $\begin{array}{c}\text { Theoretical } \\
\text { loads (ton) }\end{array}$ & $\begin{array}{c}\text { Ratio } \\
(\%)\end{array}$ \\
\hline A-1 & $5.8(6.6)$ & 6.45 & -11.3 \\
A-2 & $4.1(4.5)$ & 4.85 & -15.4 \\
B-1 & $7.1(8.5)$ & 10.3 & -31.1 \\
B-2 & $7.4(8.0)$ & 12.6 & -41.3 \\
\hline
\end{tabular}
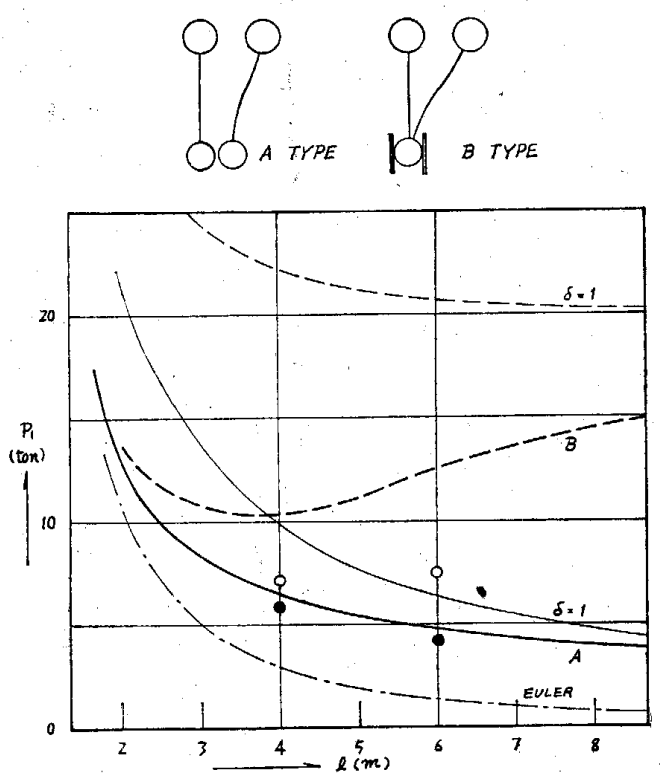

Fig. 9

えられるからである。参考までに試験機の直接の值を示 しておいた。なお各坐屈荷重は弦材の軸圧縮力 $P$ ，従っ て $M / h$ である。ての結果で下弦材を拘束した場合の実 験結果は理論值と大きな差があるが，てれは拘束の不完 全によるものと考えられる。

Fig. 9 は座屈理論曲線で, 中に実験值をプロットし ておいた。太線が試験体に対する直接の計算值である。 又細線は $\delta=1$ に対する即ち腹材の曲げ変形がない場合 の座屈荷重，逆に破線は $\delta=0$ 即ち腹材の曲げ抵抗がな く王縮弦材 1 本の才イラ一座屈荷重である。

一般にトラスの座屈耐力は $1>\delta>0$ にあるわけであ るが，下弦材を拘束した場合は拘束しない場合よりはる かに大きな差がある。これは拘束した場合上弦材の座屈 而力はほとんど腹材の抵抗のみに左右されることによ る。又スパンがある程度大きくなると座屈荷重はほとん ぞこれには左右されず，むしろ梁せいに関係する。興味 のあるのは下弦材を拘束した梁では大スパンになるほど 座屈荷重が増す場合のあることを示している。ての原因 はこのようなトラスの座屈荷重は注とんど弦材の㨝り剛 性からきまり，しかも $\delta$ はスパンが大きくなると1に近 づくためである。

Fig. 10 はトラス面の挨り角之上下弦材の㨝り角との 比 $\delta_{1}, \delta_{2}$ である。乙れは前にもふれた通り弦材㨝り剛 性の見掛上の低下率を示すもので，鍓管トラスでは座屈 耐力を知る上に特に重要である。図はダイヤルゲージに より測定した梁中央の変形で, 破壊直前までの比較的小
さな変形である。 從って測定值のば らつき計算値との 誤差も大きい。な $お \delta$ ま弦材の拘 束の有無には関係 しない。

5. 鋼管組立材 に対する設計式

剛節鋼管トラス は形鋼等で組立て られた従来のトラ ス之異なり，横座 屈に対し特異な性 質を示し極めて高 い耐荷能力を有す る。てれはひとつ

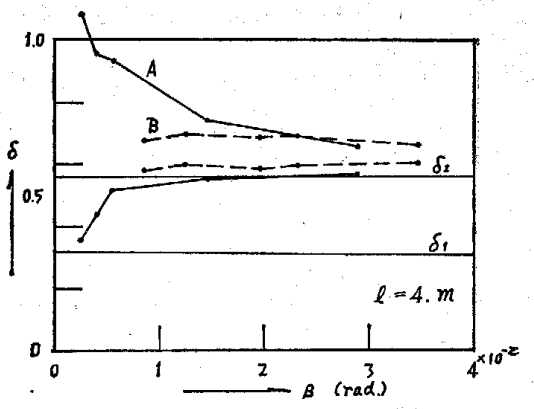

(i2)

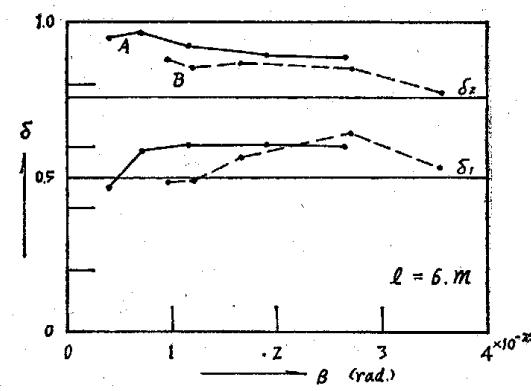

Fig. 10 には鋼管材料のもつ断面性能即ち摸り剛性の大きいとと によるが，ほかに施工上弦材と腹材とが剛に接合出来る ことにもよる。これまでの解析の結果，鋼管トラスは横 座屈に対し構造上有利なとと，そして種々な条件によっ てどのような性質を示すか等概要は知った。又座屈荷重

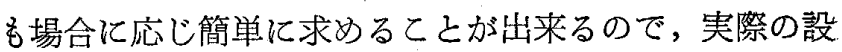
計に際してもてれら有利な点を取り入れることは意義あ るととつ考える。

トラスの横座屈に対して鋼構造計算規準では，支点間 距離を座屈長さとしたトラス圧縮弦材の構面外座屈とし て座屈検定をするよう指示している。はじめに組立材の 横座屈問題は I 形鋼と同栐単一材の横座屈として扱うこ とも，現行の設計規準通り圧縮弦材単材の構面外座屈之 して扱うととも出来るてとを述べた。勿論圧縮弦材単一 材の座屈として解析する場合も，組立材であるための考 慮をしなければならないのは当然である。たら゙現行の規 準では圧縮材単材のみの曲げ座屈として組立材であるて との考慮はされていない。特に鋼管トラスではての影響 が著るしいからなおさら設計に反映させる必要があろ う。

前に得た結果から，組立材の横座屈荷重を弦材の圧縮 力 $P_{1}$ で考光ると次の表現が出来る。

$$
P_{1}=\alpha \frac{\pi^{2}}{l^{2}} B_{1}
$$

と〉で

$$
\alpha=1+\frac{\frac{1}{h^{2}} C\left(-P_{2}+\frac{\pi^{2}}{l^{2}} B_{2}\right)}{\frac{\pi^{2}}{l^{2}} B_{1}\left(-P_{2}+\frac{\pi^{2}}{l^{2}} B_{2}+\frac{1}{h^{2}} C\right)}
$$

この $\alpha$ 一般に $\alpha \geqq 1$ の值で，組立材であるための即ち 腹材を含む下弦材の剛性・応力等による単一材の曲げ座 屈荷重に対する堌加率を表わしている。 


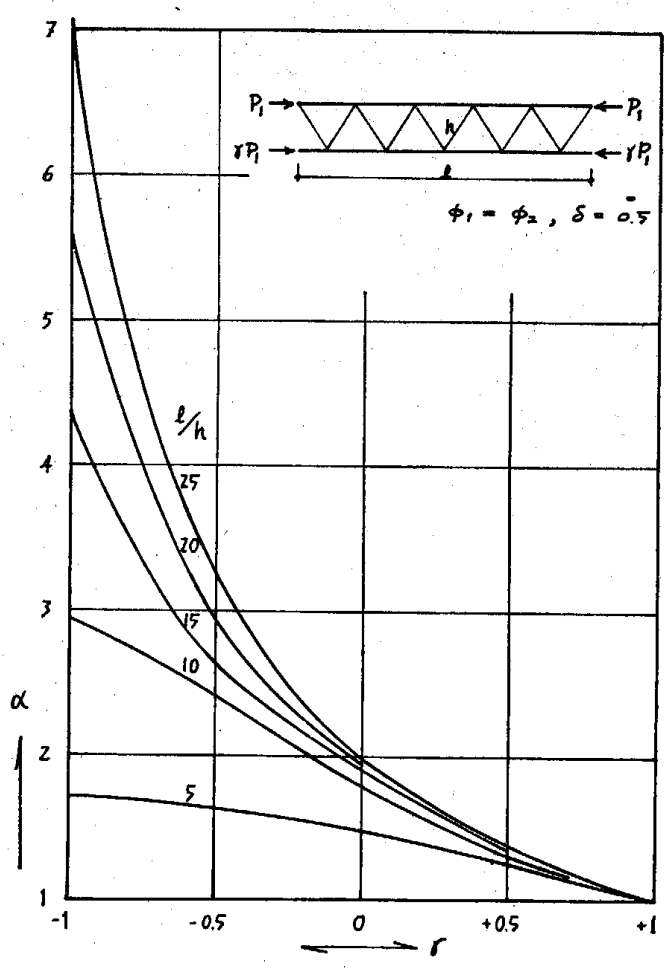

Fig. 11

圧縮材に対する $\omega$ 法の表現では，座屈応力に設計安 全率 $\omega$ を掛けそれが圧縮許容応力度 $f_{c}$ でおさえると いうことであるから，トラス圧縮弦材の座屈に対しては 次の表現となる。

$$
\begin{array}{ll}
\frac{\omega}{\alpha} \frac{P_{1}}{A_{1}} \leqq f_{c} & \text { Eq. } 8
\end{array}
$$

同様にラチス組立材・オープンウェブ部材等単一材の横 座屈と考えた場合でも，压縮側フランジの応力に対して

$$
\frac{\omega}{\alpha}\left(\frac{P}{A}+\frac{M}{Z}\right) \leqq f_{c} \quad \text { Eq. } 9
$$

として，座屈検定出采る。なお鋼構造計算規準中で述心 ているようなこの種横座屈問題に対する全体の横座屈と 圧縮弦材の面外座屈両者の検討は必要としない。両者は
異なった座屈現象ではないからである。

て〉で提案した $\omega$ 法による表現は，すへての組立材 に適用出来るばかりでなく，I 形単一材の横座屈につい ても可能である ${ }^{3)}$ っして設計に際して問題になること は， $\alpha$ 值が組立材の種々な状態ないしは条件によってど のような值となるかという点である。

実験を主体としたてれまでの解析の結果, 鋼管トラス は極めて高い横座屈耐力のあるととを知った。即ちと〉 でいう $\alpha$ 值が大きな值であることである。又形鋼トラス のように弦材の摸り剛性が低くしかも弦材と腹材の接合 が不完全なものでは，ほとんど圧縮弦材単材の座屈耐力 と変わらない。こ〉でいう $\alpha \div 1$ の場合である。

従っていが実際に重要となってくるのは剛節鋼管トラ スの場合である。Fig. 11 は一例として対称断面トラス の风值を表わしたものである。なお Eq. 7 の表現をそ のまま使うかわりに， $P_{2}=r P_{1}$ として改めて次の式を求 めた。

$$
\begin{aligned}
& \alpha= \frac{1}{28}\left[\left\{\left(1^{0}+K\right) r+(b+K)\right\}\right. \\
&-\sqrt{\left.\{(1+K) r-(b+K)\}^{2}+4 r K^{2}\right]} \quad \text { Eq. } 10 \\
& K=\left(\frac{l}{\pi h}\right)^{2} \frac{C}{B_{1}}, \quad b=\frac{B_{2}}{B_{1}}
\end{aligned}
$$

後記乙れは学位論文の一部で, 東京大学仲威雄 教授・加藤勉助教授の指導による。実験は日本鋼管研究 費による䥡管構造に関する研究の一環として行なったも のである。

[関 係 論 文]

1）鈴木敏郎：「鉄骨トラスの横座屈」日本建築学会論文報告 集 第 79 号 昭和 37 年 2 月

2）鈴木敏郎：「ウェブプレートの変形と座屈」日本建築学会 論文報告集 第 69 号 昭和 36 年 10 月

3）鈴木敏郎：「複合荷重に対主る座屈算定」日本建築学会論 文報告集 第 89 号 昭和 38 年 10 月 